\title{
TUJUAN DAN MANFAAT PERJANJIAN PERKAWINAN
}

\author{
Oleh: \\ Haedah Faradz \\ Fakultas Hukum Universitas Jenderal Soedirman Purwokerto
}

\begin{abstract}
Societal perception which still consider dim towards Marriage Agreement makes Marriage Agreement seldom doing by layman. This case happens because Marriage Agreement considers does not ethic, and even does not fit with oriental custom. Actually Law No.1 Year 1974 concerning Marriage law has not yet cleared to arrange Marriage Agreement, it only declares that both parties that is husband and wife, article 29 Law No.1 Year 1974 mentioned above can conclude that inscribed Agreement which mentioned is Marriage Agreement. In fact Marriage Agreement carries a nice purpose and profit, because it is a preventive action to simplify distribution of their property.
\end{abstract}

Kata kunci: Perkawinan dan perjanjian

\section{A. Pendahuluan}

Tindakan preventif untuk mengantisipasi terjadinya konflik sebelum melakukan perkawinan adalah dengan membuat perjanjian perkawinan. Perjanjian perkawinan belum merupakan lembaga hukum yang terbiasa dilakukan di masyarakat yang semula hanya merupakan lembaga hukum khusus bagi anggota masyarakat Indonesia yang tunduk pada KUH Perdata yang disebut dengan istilah perjanjian kawin. Bab V UU No.1 Tahun 1974 tentang Perkawinan, maupun dalam Kompilasi Hukum Islam (KHI) secara jelas telah mengatur masalah perjanjian perkawinan, namun dalam praktiknya masih jarang ditemui adanya perjanjian perkawinan, hal ini oleh sebagian besar masyarakat masih dianggap tidak etis dan pamali. Karena bukan hanya calon pasangan pengantin saja yang bertengkar ketika ide perjanjian pernikahan dilontarkan, namun jika merembet menjadi masalah keluarga antara calon besan, sebab perjanjian perkawinan dianggap tindakan matrialis. Tetapi dengan semakin bertambahnya angka perceraian, keinginan orang untuk membuat perjanjian perkawinan, karena biasanya pasangan suami isteri yang bercerai akan meributkan pembagian harta perkawinan.

Dengan membuat perjanjian perkawinan, suami isteri mempunyai kesempatan untuk saling terbuka. Mereka dapat berbagi rasa atas keinginan-keinginan yang hendak disepakati tanpa harus merugikan salah satu pihak.
Mamang kalau melihat status hukumnya, perjanjian perkawinan itu sifat dan hukumnya tidak wajib dan juga tidak diharamkan. Artinya, perjanjian perkawinan itu sifat dan hukumnya adalah mubah (boleh-boleh saja). Namun dengan adanya perjanjian perkawinan, hubungan suami isteri akan terasa aman karena jika suatu saat hubungan mereka ternyata "retak" bahkan berujung pada perceraian, maka ada sesuatu yang dapat dijadikan pegangan dan dasar hukum. ${ }^{1}$ Berdasarkan hal di atas, maka tulisan ini dimaksudkan untuk menjelaskan tujuan dan manfaat dari perjanjian perkawinan.

\section{B. Pembahasan}

Perjanjian perkawinan merupakan istilah ynag diambilkan dari judul Bab V UU No.1 th 1974 yang berisi satu pasal, yaitu pasal 29. Sedangkan mengenai pengertian perjanjian perkawinan ini tidak diperoleh penjelasan, hanya mengatur tentang kapan perjanjian kawin itu dibuat, hanya mengatur tentang keabsahanya, tentang saat berlakunya dan tentang dapat diubahnya perjanjian itu. Jadi sama sekali tidak mengatur tentang materi perjanjian seperti yang diatur dalam KUH Perdata.

Menurut Happy Susanto, perjanjian perkawinan adalah perjanjian yang dibuat oleh pasangan calon pengantin, baik laki-laki mau

\footnotetext{
Muchsin, Perjanjian Perkawinan Dalam Persfektif Hukum Nasional, Jakarta : Varia Peradilan No. 273 edisi Agustus 2008.
} 
pun perempuan sebelum perkawinan mereka dilangsungkan, dalam isi perjanjian tersebut mengikat hubungan perkawinan mereka. ${ }^{2}$ Secara umum, perjanjian perkawinan berisi tentang pengaturan harta kekayaan calon suami isteri. Tujuan dari pembuatan perjanjian perkawinan adalah untuk mengatur akibat-akibat perkawinan yang menyangkut harta kekayaan. ${ }^{3}$

Perjanjian kawin ialah perjanjian (persetujuan) yang dibuat oleh calon suami isteri, sebelum atau pada saat perkawinan dilangsungkan untuk mengatur akibat-akibat perkawinan terhadap harta kekayaan mereka. ${ }^{4}$ Perjanjian perkawinan tidak hanya sebatas memperjanjikan masalah keuangan/harta, ada hal lain yang juga penting diperjanjikan, misalnya tentang kekerasan dalam rumah tangga, memperjanjikan salah satu pihak untuk tetap melanjutkan kuliah meski sudah menikah dan sebagainya. ${ }^{5}$

Perjanjian Perkawinan umumnya mengatur ketentuan bagaimana harta kekayaan mereka akan dibagi jika terjadi perpisahan hubungan antar keduanya, baik itu karena perceraian maupun kematian. Perjanjian Perkawinan juga memuat hal-hal yang berkenaan dengan kepentingan masa depan rumah tangga mereka.Hal ini seperti tercantum dalam pasal 29 undang-undang No.1 tahun 1974.

Pasal 29 UU No.1 th 1974 mengatur tentang Perjanjian perkawinan disebutkan:

Ayat (1)

Pada waktu atau sebelum perkawinan dilangsungkan, kedua belah pihak atas persetujuan bersama dapat mengajukan perjanjian tertulis yang disahkan oleh pegawai pencatat perkawinan, setelah masuk isinya berlaku juga terhadap pihak ketiga tersangkut.

Ayat (2)

Perjanjian tersebut tidak dapat disahkan bilamana melanggar batas-batas hukum agama dan kesusilaan.

Ayat (3)

2 Happy Susanto, Pembagian Harta Gono-Gini Saat Terjadinya Perceraian, Jakarta: Visimedia, hlm. 78

3 Soetojo Prawirohamidjojo, Hukum Orang dan keluarga, Surabaya: Airlangga University Press, hlm. 87

4 Soetojo Prawirohamidjojo, 1986, Pluralisme dalam perundang-undangan perkawinan di Indonesia, Surabaya: Airlangga University Press, hlm. 57

5 Muchsin, Op.cit, hlm. 7
Perjanjian tersebut dimulai berlaku sejak perkawinan dilangsungkan.

Ayat (4)

Selama perkawinan berlangsung perjanjian tersebut tidak dapat diubah, kecuali dari kedua belah pihak ada persetujuan untuk merubah dan perubahan tidak merugikan pihak ketiga.

Sebenarnya UU No.1 Tahun 1974 tidak mengatur secara tegas tentang perjanjian perkawinan, hanya dinyatakan bahwa kedua belah pihak dapat mengadakan perjanjian tertulis yaitu Perjanjian Perkawinan. Dalam ketentuan ini tidak disebutkan batasan yang jelas, bahwa Perjanjian Perkawinan itu mengenai hal apa. Sehingga dapat dikatakan bahwa Perjanjian Perkawinan UU ini mencakup banyak hal. Disamping itu UU perkawinan tidak mengatur lebih lanjut tentang bagaimana hukum Perjanjian Perkawinan yang dimaksud. ${ }^{6}$

Peraturan Pemerintah No. 9 Tahun 1975 tentang pelaksanaan UU No.1 Tahun 1974 tentang perkawinan tidak mengatur lebih lanjut bagaimana tentang Perjanjian Perkawinan dimaksud, hanya disebutkan bahwa kalau ada Perjanjian Perkawinan harus dimuat di dalam akta perkawinan (Pasal 12 h). ${ }^{7}$ Ketentuan tentang Perjanjian Perkawinan juga diatur dalam KUH Perdata Pasal 139, yang menetapkan bahwa dalam perjanjian kawin itu kedua calon suami isteri dapat menyimpangi ketentuan-ketentuan yang ditetapkan dalam harta bersama, asal saja penyimpangan-penyimpangan tersebut tidak bertentangan dengan kesusilaan dan ketertiban umum. Pada umumnya perjanjian kawin dibuat:

1. Bilamana terdapat sejumlah harta kekayaan yang lebih besar pada salah satu pihak dari pada pihak yang lain.

2. Kedua belah pihak masing-masing membawa masukan yang cukup besar.

\footnotetext{
Djaja S. Meliala, 2006, Perkembangan Hukum Perdata tentang Orang dan Hukum Keluarga,, Bandung: Nuansa Aulia, hlm. 67

7 K. Wantjik Saleh, 1980, Hukum Perkawinan Indonesia, Jakarta: Ghalia Indonesia, hlm. 32
} 
3. Masing-masing mempunyai usaha sendirisendiri sehingga andaikata salah satu jatuh pailit yang lain tidak tersangkut.

4. Atas hutang-hutang yang mereka buat sebelum kawin, masing-masing akan bertanggung gugat sendiri-sendiri.

Perjanjian sebagaimana tersebut haruslah dilaksanakan sebelum perkawinan dilangsungkan dan haruslah dibuat dalam bentuk akta otentik dimuka notaris, akta otentik itu sangat penting karena dapat dijadikan bukti dalam persidangan pengadilan apabila terjadi sengketa tentang harta bawaan masing-masing. Jika tidak ada perjanjian kawin yang dibuat sebelum perkawinan dilaksanakan maka semua harta suami dan isteri terjadi perbauran. Tentang Perjanjian kawin ini dibenarkan oleh peraturan perundang-undangan sepanjang tidak menyalahi tata susila dan ketentraman umum yang berlaku dalam masyarakat. ${ }^{8}$

Pasal 47 ayat (1) Kompilasi Hukum Islam disebutkan bahwa pada waktu atau sebelum perkawinan dilangsungkan kedua calon mempelai dapat membuat perjanjian tertulis yang disahkan oleh pegawai pencatat nikah, mengenai kedudukan harta dalam perkawinan.

Pasal 47 ayat (2) perjanjian tersebut dalam ayat 1 dapat meliputi pencampuran harta pribadi dan pemisahan harta pencaharian masing-masing sepanjang hal itu tidak bertentangn dengan hukum islam. ${ }^{9}$

Dari segi tujuan dan manfaat dibuatnya Perjanjian perkawinan masih sedikit calon pengantin yang memandang hal ini sebagai sesuatu yang positif. Hal ini dikarenakan masih dianggap tabu dan pamali di masyarakat. Ada sebagian masyarakat yang dapat menerima konsep pemikiran tentang pembuatan Perjanjian Perkawinan, tetapi lebih banyak masyarakat yang belum menerimanya, disebabkan adanya pandangan negatif yang menganggap Perjanjian Perkawinan sebagai sesuatu yang tidak umum, tidak etis, kecurigaan, egois,

\footnotetext{
8 Abdul Manan, 2003, Aneka Masalah Hukum Material dalam Praktek Peradilan Agama, Jakarta: Pustaka Bangsa, hlm. 153-154

9 Abdurrahman, 2007, Kompilasi Hukum Islam di Indonesia, Jakarta: CV Akademika Pressindo, hlm. 124
}

tidak sesuai dengan budaya orang timur yang penuh etika.

Sebaliknya Perjanjian Perkawinan yang dianggap masih tabu dilakukan oleh masyarakat awam justru telah menjadi gejala baru di kalangna tertentu seperti selebritis, pengusaha dan lain-lain. Mereka umumnya berpandangan bahwa dengan adanya Perjanjian Perkawinan harta miliknya akan terjamin aman apabila terjadi perceraian. Dalam Perjanjian Perkawinan yang perlu dipertimbangkan adalah. ${ }^{10}$

1. Keterbukaan dalam mengungkapkan semua detail kondisi keuangan baik sebelum mau pun sesudah pernikahan. Berapa jumlah harta bawaan masing-masing pihak sebelum menikah dan bagaimana potensi bertambahnya sejalan dengan meningkatnya penghasilan atau karena hal lain misalnya menerima warisan. Kemudian berapa jumlah hutang bawaan masing-masing pihak sebelum menikah, bagaimana potensi hutang setelah menikah dan siapa yang bertanggung jawab terhadap pelunasan hutangnya. Tujuanya agar tahu persis apa yang akan di terima dan apa yang akan dikorbankan jika perkawinan berakhir, sehingga tidak ada pihak yang merasa dirugikan nantinya.

2. Kerelaan perjanjian pranikah harus disetujui dan ditandatangani oleh kedua belah pihak secara sukarela tanpa paksaan. Jika salah satu pihak merasa dipaksa, karena diancam atau berada dalam tekanan sehingga terpaksa menandatanganinya, perjanjian pranikah bisa diancam batal karenanya.

3. Pejabat yang obyektif. Pilihlah pejabat berwenag yang bereputasi baik dan bisa menjaga obyektivitas, sehingga dalam membuat isi perjanjian pranikah bisa tercapai keadilan bagi kedua belah pihak.

4. Notariil. Perjanjian pranikah sebaiknya tidak dibuat di bawah tangan tetapi harus di sahkan oleh notaris. Kemudian harus di catatkan pula dalam lembaga pencatatan perkawinan, artinya pada saat pernikahan di langsungkan perjanjian pranikah juga harus

\footnotetext{
${ }^{10}$ Mike Rini, Perlukah Perjanjain Pranikah, dikutip dari Danareksa. Com tanpa halaman tanpa tahun
} 
252 Jurnal Dinamika Hukum

Vol. 8 No. 3 September 2008

disahkan pula oleh pegawai pencatat perkawinan (KUA maupun Kantor Catatan Sipil).

Maka dengan membuat Perjanjian perkawinan pasangan suami isteri mempunyai kesempatan untuk saling terbuka,dan bisa berbagi rasa atas keinginan yang telah disepakati untuk menjalani isi perjanjian tersebut. Biasanya perjanjian perkawinan dibuat untuk kepentingan perlindungan hukum terhadap harta masing-masing suami isteri, karena UU Perkawinan tidak mengatur tujuan Perjanjian Perkawinan, segalanya diserahkan kepada kedua belah pihak yaitu suami dan isteri.

Pada dasarnya Perjanjian Perkawinan tidaklah seburuk yang menjadi anggapan masyarakat. Hal ini terjadi karena Perjanjian Perkawinan bagi orang kebanyakan adalah kurang etis tidak sesuai dengan budaya orang timur. Mengingat pentingnya Perjanjian Perkawinan ternyata cukup banyak manfaatnya bagi suami isteri. Tanpa Perjanjian Perkawinan, maka dalam proses pembagian harta gono-gini sering terjadi pertikaian. Karena itu manfaat dari Perjanjian Perkawinan adalah dapat mengatur penyelesaian dari masalah yang kira-kira akan timbul selama perkawinan, antara lain: ${ }^{11}$

1. Tentang pemisahan harta kekayaan, jika tidak ada harta gono-gini syaratnya, harus dibuat sebelum pernikahan dan harus di catatkan di tempat pencatatan perkawinan

2. Tentang pemisahan hutang, dalam perjanjian perkawinan dapat diatur mengenai masalah hutang yang akan tetap menjadi tanggungan dari pihak yang membawa hutang. Hutang yang dimaksud adalah hutang yang terjadi sebelum pernikahan, selama pernikahan, setelah perceraian bahkan kematian.

3. Tanggung jawab terhadap anak-anak hasil pernikahan tersebut terutama mengenai masalah biaya hidup anak, dan biaya pendidikanya harus diatur sedemikian rupa berapa besar kontribusi masing-masing orang tua, dalam hal ini tujuanya agar kesejahteraan anak-anak tetap terjamin

\section{Penutup}

Perjanjian Perkawinan adalah mempunyai tujuan dan manfaat yang baik yaitu sebagai tindakan preventif apabila terjadi perceraian, karena dengan dibuatnya Perjanjian Perkawinan akan mempermudah pembagian harta gonogini.Dengan jalan ini perselisihan antar mantan pasangan suami istri yang bercerai,tidak perlu berkepanjangan. Hanya saja pemahaman dan persepsi masyarakat yang masih tabu dalam memandang Perjanjian Perkawinan, sehingga Perjanjian Perkawinan masih jarang dilakukan.

\section{Daftar Pustaka}

Abdurrahman. 2007. Kompilasi Hukum Islam di Indonesia. Jakarta: Akademika Pressindo;

Muchsin. 2008. Varia Perdilan, Jakarta: Ikatan Hakim Indonesia;

Meliala,S Djaja. 2006. Perkembangan Hukum Perdata tentang Orang dan Hukum Keluarga. Bandung: Nuansa Aulia;

Manan, Abdul. 2003. Aneka Masalah Hukum Material Dalam Praktek Peradilan Agama. Jakarta: Pustaka bangsa;

Prawirohamidjojo, Soetojo. 1990. Hukum Orang dan Keluarga. Surabaya: Airlangga University Press;

-.-----.-. 1986. Pluralisme Dalam PerundangUndangan Perkawinan Di Indonesia, Surabaya: Airlangga University Press;

Rini, Mike. Perlukah Perjanjian Pranikah. Danareksa.com.

Susanto, Happy, 2008, Pembagian Harta GonoGini Saat Terjadi Perceraian. Jakarta: Visimedia;

Saleh K Wantjik. 1980. Hukum Perkawinan Indonesia. Jakarta: Ghalia Indonesia;

KUH Perdata

UU No.1 Tahun 1974 tentang Perkawinan.

PP No.9 Tahun 1975 tentang Perlaksanaan UU Perkawinan.

Intruksi Presiden RI No.1 th 1991.

\footnotetext{
${ }^{11}$ Mike Rini, Ibid tanpa halaman tanpa tahun
} 